\title{
The relationship between assessments of hospital services and the quality of hospital Internet presence
}

\section{Analiza związku pomiędzy oceną działalności placówek szpitalnych i jakością ich obecności w przestrzeni internetowej}

\author{
Marcin Grysztar ${ }^{1, C D}$, Aleksandra Pieczarka ${ }^{2, B, C}$, Diana Wirchomska ${ }^{2, B, C}$, Mariusz Duplaga ${ }^{1, A, C-F}$ \\ ${ }^{1}$ Department of Health Promotion, Faculty of Health Sciences, Jagiellonian University Medical College, Kraków, Poland \\ ${ }^{2}$ Student Research Group of Health Promotion, Faculty of Health Sciences, Jagiellonian University Medical College, Kraków, Poland \\ A - research concept and design; $\mathrm{B}$ - collection and/or assembly of data; $\mathrm{C}$ - data analysis and interpretation; \\ $\mathrm{D}$ - writing the article; $\mathrm{E}$ - critical revision of the article; $\mathrm{F}$ - final approval of the article
}

Pielęgniarstwo iZdrowie Publiczne, ISSN 2082-9876 (print), ISSN 2451-1870 (online)

Piel Zdr Publ. 2018;8(4):237-244

Address for correspondence

Marcin Grysztar

E-mail:m.grysztar@gmail.com

Funding sources

The study is a statutory project of Jagiellonian University Medical College, Kraków, Poland, №. K/ZDS/006112.

Conflict of interest

None declared

Received on November 22, 2017

Reviewed on January 10, 2018

Accepted on April 23, 2018

Cite as

Grysztar M, Pieczarka A, Wichromska D, Duplaga M. The relationship between assessments of hospital services and the quality of hospital Internet presence. Piel Zdr Publ. 2018;8(4):237-244. doi:10.17219/pzp/90355

DOI

10.17219/pzp/90355

Copyright

○ 2018 by Wroclaw Medical University

This is an article distributed under the terms of the

Creative Commons Attribution Non-Commercial License

(http://creativecommons.org/licenses/by-nc-nd/4.0/)

\begin{abstract}
Background. Healthcare providers are not allowed to conduct classical marketing activities. One of the acceptable forms of presentation of their services is maintaining their own website.

Objectives. The main aim of the study was to analyze the relationship between assessment results of the services provided by multispecialty hospitals and the quality of their websites.

Material and methods. The analysis covered 20 websites of hospitals ranked as the top 10 and the last 10 in the "Golden Hundred" of the "Safe Hospital 2016" ranking released by the Center for Monitoring Quality Polish National Center for Quality Assessment in Healthcare (rNCQA). The quality of hospital websites was assessed in 4 domains including access, creation and transfer of knowledge, and the scope of information provided.
\end{abstract}

Results. The mean scores for the quality of websites for the top 10 hospitals in the INCQA was $29.67 \pm 4.01$; the mean score for the last 10 was $41.40 \pm 5.4(p=0.31)$. There was a significant difference between the 2 groups of hospitals in the score related to creation of knowledge (1.67 \pm 2.36 vs $3.7 \pm 1.89$; $p=0.047$ ) and to the scope of information provided ( $19.4 \pm 1.35$ vs $18.2 \pm 1.14 ; p=0.026$ ). The total score for website quality and the score for the scope of information provided were correlated with the results of the assessment of "management" in the rNCQA (Spearman's rho coefficient 0.46 and 0.56 , respectively; $p$ for both $<0.05)$. Interestingly, the results of the assessment of "management" in the rNCQA were negatively correlated with the domain of creation of information on the websites of the hospitals (Spearman's rho $=-0.54$ ). Booking online was the most common type of e-health service provided by the hospitals through their websites (70\% among the lowest 10 hospitals and 100\% of the top 10 hospitals).

Conclusions. The quality of the websites maintained by multispecialty hospitals is not related to the quality of services offered. E-health services other than online booking are rarely provided by Polish hospitals.

Key words: website, e-health, healthcare quality, hospital, quality 


\section{Streszczenie}

Wprowadzenie. Placówki ochrony zdrowia nie mogą prowadzić działalności marketingowej i reklamy, typowej dla firm i instytucji komercyjnych. Jedną z dopuszczalnych form prezentacji swojej działalności jest utrzymywanie strony internetowej.

Cel pracy. Celem badania była analiza zależności pomiędzy oceną działalności szpitali wielospecjalistycznych i jakością ich stron internetowych.

Materiał i metody. Badaniem objęto strony WWW placówek, które zajęły pierwsze i ostatnie 10 miejsc w rankingu Centrum Monitorowania Jakości (rcMJ) „Bezpieczny Szpital 2016". Jakość stron WWW oceniano w 4 domenach: udostępniania, tworzenia, transferu i zakresu informacji.

Wyniki. Średni wskaźnik oceny stron internetowych pierwszych 10 szpitali w rCMJ wynosił 29,67 $\pm 4,01$, a 10 ostatnich 41,40 $\pm 5,4$ ( $p=0,31)$. Potwierdzono znaczące różnice pomiędzy stronami WWW obydwu grup w zakresie tworzenia informacji (1,67 $\pm 2,36$ vs 3,7 $\pm 1,89 ; p=0,047)$ i zakresu informacji $(19,4 \pm 1,35$ vs $18,2 \pm 1,14 ; p=0,026)$. Pomiędzy oceną domeny zakresu informacji i całkowitym wynikiem oraz oceną zarządzania wg rCMJ istniała znacząca statystycznie korelacja (współczynnik rho Spearmana; odpowiednio 0,46 i 0,56). Pomiędzy oceną zarządzania a domeną tworzenia informacji stwierdzono istotną ujemną korelacją (rho Spearmana = -0,54). Spośŕód usług e-zdrowia szpitale najczęściej udostępniały rejestrację online (odpowiednio 70\% i 100\%).

Wnioski. Jakość stron internetowych szpitali nie odzwierciedla jakości oferowanych usług. Dostępność usług e-zdrowotnych (poza e-rejestracija) w szpitalach jest ograniczona.

Słowa kluczowe: jakość usług zdrowotnych, e-zdrowie, strona internetowa, szpital, jakość

\section{Background}

The provision of health-related information on the Internet is the subject of many controversies. On the one hand, the Internet has revolutionized access to information about health, diseases and treatment for patients and the general public. On the other hand, the content of health-related websites may be manipulated to encourage the purchase of products with questionable therapeutic effects or to promote alternative medicine. The problem of the reliability of health-related information on the Internet quickly became a focus of interest for professional communities involved in e-health and public health. This is evidenced by the number of initiatives aiming at a systematic assessment of websites related to health and medicine. ${ }^{1-3}$ The Code of Conduct proposed by the Health On the Net Foundation (HON) is one of the best-known initiatives, and is frequently referred to by the providers of health-related websites. ${ }^{4}$

Rocha et al. proposed a generic approach to assessing the quality of health-related websites. They distinguished 3 main dimensions of quality assessment: technical, content-related and service-related. Assessments of technical quality are usually based on the software quality models or standards and on methods focusing on issues of usability. Assessments of the quality of content depend on the context and the type of website being considered. Finally, evaluations of the quality of services consider the types of services provided and results of the assessments of user satisfaction. In the case of health-related websites, the services provided correspond to functionalities or applications defined as e-health, e.g., e-booking or e-prescriptions. ${ }^{5}$

A considerable portion of health-related Internet resources originate from healthcare institutions. In Poland, healthcare providers are not allowed to conduct marketing activities in relation to their services. According to Polish law, healthcare institutions may publicly present information about the scope and the types of health services they provide, but the content and form of such communication cannot take the form of an advertisement. ${ }^{6} \mathrm{~A}$ hospital website is an acceptable form of presenting information about medical services offered. As the information provided on such sites is supported by the authority of health professionals, there are fewer problems with the credibility of the content. However, other aspects can be important when the quality of websites of healthcare institutions is considered.

The importance of hospitals maintaining their own websites was appreciated a long time ago. Therefore, attempts to assess the quality of hospital websites were conducted in parallel to initiatives focused on ensuring the reliability of web-based health information. It seems obvious that hospitals that care about their reputation and endeavor to ensure good communication with their current or future patients try to ensure that their websites are attractive and functional. It might also be expected that the quality of a hospital website may to some extent reflect the quality of the medical services offered.

Numerous studies have investigated the availability and quality of hospital websites. Initially, researchers focused on the quality of health information provided on websites ${ }^{7}$; then criteria based on the content provided and the technical functionality were developed. Many authors have made efforts to provide assessments of the quality of websites of public and private hospitals in their countries. Randeree and Rao carried out an evaluation of a sample of hospital websites in the USA, combining assessment of content and functionality. The key assessment criteria applied by those authors included access/usability, audience, accuracy, timeliness, content, authority, and security/privacy. ${ }^{8}$ 
Patsioura et al. developed an evaluation framework of hospital websites including 9 groups of criteria. ${ }^{9}$ The framework consisted of 67 individual items. For example, the group called "information gathering" encompassed 6 criteria: hospital general information, hospital specific information, health information, up-to-date information, and disclosure of credentials and links. Three criteria assigned to the group called "communication and transaction with the hospital" were: contact and communication, interaction and transaction, and user support and ease of use. ${ }^{9}$

Mira et al. developed a tool to assess to what extent a hospital website is oriented toward the public. It consisted of 73 individual criteria related to the scope of information provided on the website, its accessibility and functionality. ${ }^{10}$ This approach was to some extent adopted by Maifredi et al. in order to carry out an evaluation of the quality of hospital websites in Italy. ${ }^{11}$ The criteria used by this team included the technical characteristics of the website, the scope of information about the hospital and the services provided, interactive services online and "external activities". Technical characteristics included the availability of an internal search tool, the general accessibility of the site, its compliance with Web Accessibility Initiative (WAI) guidelines for accessibility by disabled persons, and its concordance with the principles of the $\mathrm{HON}$ Foundation. The domain of information about the hospital covered the history of the hospital, its location, access information, and contact details. The domain of medical services consisted of 25 issues related to admission, hospitalization and discharge from the hospital, as well as information about the health professionals employed in the hospital. Within the domain of interactive services, the availability of online booking, the options for communication with hospital via the Internet (e.g., by e-mail) and health-related forum were checked. Finally, "external activities" covered options for obtaining health information, information about job opportunities and listings of events organized by the hospital. In total, 89 individual elements were included in the evaluation. ${ }^{11}$

A different approach to the assessment of website quality originates from the concept of knowledge management used in e-commerce. ${ }^{12}$ Lee et al. developed a model of assessment based on this approach, but adjusted it to websites containing health content, including those developed by healthcare institutions. Their model anticipated 3 domains of assessment: access to knowledge, creation of knowledge and transfer of knowledge. The domain of access to knowledge was related to the mechanisms providing users with access to the website and its content, e.g., browsing, searching, personalization, and the use of multimedia. Knowledge creation denoted capturing data originating from users, e.g., socio-demographic characteristics, preferences or behaviors, in order to develop knowledge useful both for the website provider and its users. Finally, knowledge transfer considered mechanisms supporting the sharing of information among users and between users and the website provider. ${ }^{13}$

Minifie et al. assessed the evolution of hospital websites in the USA and elsewhere in the period from 1999 to 2004. They distinguished 4 phases of website evolution: the basic site, e-marketing, interactive phase, and transactional phase. The websites of American hospitals showed greater progress in achieving higher levels of development than non-American hospitals. This finding apparently reflected the fact that the USA was a leader in the development of the e-health environment from the beginning. ${ }^{14}$

The main objective of our study was to analyze the relationship between the results of assessments of the services provided by multispecialty hospitals in Poland and the quality of their websites. The evaluation of website quality was carried out using a tool consisting of 4 domains: 3 related to the mechanisms of knowledge management and 1 reflecting the scope of information provided on the website.

\section{Material and methods}

\section{Selection of hospital websites}

The study was based on a systematic evaluation of the quality of websites of multispecialty hospitals that were ranked in the positions 1-10 and 91-100 in the "Golden Hundred" of the ranking titled "Safe Hospital 2016" prepared under the auspices of the Polish National Center for Quality Assessment in Healthcare (NCQA). It was the $13^{\text {th }}$ edition of the published ranking of the 100 best multispecialty hospitals (rNCQA). The ranking is based on responses to questionnaires distributed to the hospitals by the NCQA. Therefore, it considers only hospitals that provided adequate data. In 2016, completed questionnaires were returned by 226 hospitals from all over Poland. The results of a comparison of multispecialty hospitals providing surgical services are published for the 100 best hospitals (the "Golden Hundred"). The hospitals that provided data but were not classified within the first 100 places obtain confidential access to the results of the ranking. ${ }^{15}$

The ranking is based on assessment in 15 areas, including buildings, asset management, utilities and infrastructure, the operating block, the system of sterilization, diagnostics, information systems, management, medication policies, quality of services, certificates, comfort of stay in the hospital, analysis of complaints and events, personnel, and finances. The individual categories have varying weights. Detailed information on the rules governing the development of the ranking is available on the NCQA website. ${ }^{15}$ The results of the ranking for the "Golden Hundred" are available as totals and subtotals for "management", "quality of care" and "medical care". The category of "management" is based on the results achieved 
by the hospital in the areas of buildings, asset management, maintenance of utilities and infrastructure, the information system, management, and finances. The score for the category of "quality of care" is calculated from the results in the areas of the quality of services, certificates, comfort of stay in the hospital, and analysis of complaints and events. The subtotal for the $3^{\text {rd }}$ category, "medical care", is derived from the results for the operating block, the system of sterilization, diagnostics, medication policies, and personnel.

\section{The assessment of the quality of hospital websites}

Quality of hospital websites was assessed using a tool encompassing 4 main categories: access to information, creation and transfer of knowledge, and the scope of information (Table 1). The tool was developed following a review of literature focused on strategies for assessing websites maintained by healthcare providers. Basically, it combines the approach stemming from the concept of knowledge management proposed by Lee et al. and the category of the scope of information included in the approach used by Maifredi et al. ${ }^{11,13}$ As the availability of e-health services in Poland is still limited, assessment of their availability was not included in the tool. Instead, their availability was assessed separately.

The list of individual criteria included in all 4 categories is presented in Table 1 . Each individual criterion was assigned 1 point. The results of the assessments of the individual criteria were summed up, and the raw score for the main category was scaled in the range from 0 to 20 . In this way, the total score for website quality could assume values ranging from 0 to 80 . The assessment of individual criteria was carried out by 2 members of the team separately. In cases of discordant opinions, consensus was sought, and if divergence persisted, a $3^{\text {rd }}$ member of the team was asked for a decisive vote.

\section{Assessment of e-health services offered}

Additionally, the provision of e-health services through the hospital website was assessed. A list of e-health services was established after reviewing the literature and adjusting for the applicability of Internet technologies (Table 2). In the case of teleconsultation services offered to other

Table 1. The criteria of the quality of hospital websites

Tabela 1. Kryteria jakości stron internetowych szpitali

\begin{tabular}{|c|c|}
\hline Main category & Criteria \\
\hline \multirow{5}{*}{ 1. Knowledge access } & 1.1. Content searching (mechanism of searching the content of the website/portal) \\
\hline & 1.2. Browsing (site map, glossary, other option for site content browsing) \\
\hline & 1.3. Adjusting information to users (ability to enter users' status and preferences) \\
\hline & $\begin{array}{l}\text { 1.4. Accessibility for persons with disability (compliance with Web Content Accessibility Guidelines } \\
\text { - quality of information on the website, alternative channels: audio for text, verbal description of videos) }\end{array}$ \\
\hline & 1.5. Diversity of types of information (photos, graphics, videos, audio, Flash presentations, other) \\
\hline \multirow{3}{*}{ 2. Knowledge creation } & 2.1. Capturing information from users (e.g., registration of users) \\
\hline & 2.2. Receiving feedback from users (e.g., commentaries) \\
\hline & 2.3. Tools for collecting domain-specific information (questionnaires, voting) \\
\hline \multirow{6}{*}{ 3. Knowledge transfer } & 3.1. Communication between hospital and users (options for questions, e.g., "ask an expert") \\
\hline & 3.2. Communication among users (discussion forum, other) \\
\hline & 3.3. Support in synchronic mode (chat, videoteleconference) \\
\hline & 3.4. Sharing resources (links to external websites, materials shared by users) \\
\hline & 3.5. User support (online tutorials, demos, hotline, on-screen help) \\
\hline & 3.6. Alerts (newsletter, event calendar, e-mail alerts) \\
\hline \multirow{10}{*}{ 4. Scope of information } & 4.1. Information about hospital: history, profile, regional importance \\
\hline & 4.2. Organizational structure \\
\hline & 4.3. Locations, access details \\
\hline & 4.4. Contact details - hospitals, units \\
\hline & 4.5. Information about employees including physicians \\
\hline & 4.6. Information about services offered \\
\hline & 4.7. Information about criteria for receiving services \\
\hline & 4.8. Information about admission, hospitalization and discharge, as well as about preparation for planned procedures \\
\hline & 4.9. Information about diseases and about treatments offered by the hospital \\
\hline & 4.10. Access to information about the quality of services offered \\
\hline
\end{tabular}


Table 2. E-health services included in the assessment

Tabela 2. Usługi e-zdrowia uwzględnione w ocenie

E-health service
1. Booking online
2. Patient access to electronic medical record
3. Online consultations for patients
4. Telemonitoring of patients with chronic conditions (tele-ECG,
electronic diary)
5. Teleconsultation services for other healthcare providers
6. Educational resources addressed to patients
7. Educational resources for health professionals
8. Online programmes supporting healthy lifestyle (weight loss,
addictions)
9. Video streaming addressed to patients
10. Video streaming addressed to health professionals
11. The use of social media for promotion and communication
with users

healthcare providers, relevant information about options for cooperation were searched on the hospital website.

\section{Statistical methods}

The statistical analysis was performed using the STATISTICA PL v. 13 software package (StatSoft Inc., Tulsa, USA). Partial and total scores resulting from the assessment of the quality of websites were presented as means and standard deviations. In cases of qualitative variables, frequencies were provided. The differences between the scores for the quality of websites achieved by the 2 groups of hospitals included in the rNCQA "Golden Hundred" were analyzed with the Mann-Whitney $U$ test. The results of the nonparametric analysis of correlations between the scores for the quality of websites and the rNCQA results were expressed as Spearman's rho coefficients.

\section{Results}

The mean total score for website quality of the top 10 hospitals from the "Golden Hundred" in the rNCQA was $39.67 \pm 4.10$ (mean \pm standard deviation $(S D)$ ), and of the last 10 it was $41.40 \pm 5.40(p=0.31)$. The differences between the 2 groups of hospitals were statistically significant in the category of knowledge creation $(1.67 \pm 2.36$ vs $3.70 \pm 1.89 ; \mathrm{p}=0.047)$ and the scope of information (19.40 \pm 1.35 vs $18.20 \pm 1.14 ; \mathrm{p}=0.026$ ) (Table 3 ).

\section{Correlations between website quality and the results of the rNCQA}

The nonparametric analysis of correlations between the results of the assessment of website quality and the results
Table 3. Comparison of partial and total scores of the quality of websites in 2 groups of hospitals

Tabela 3. Porównanie częściowej i całkowitej oceny jakości stron internetowych dla 2 grup szpitali

\begin{tabular}{|l|c|c|c|}
\hline Website quality & $\begin{array}{c}\text { Websites } \\
\text { of hospitals ranked } \\
\text { as } 1-10 \\
\text { in the rNCQA } \\
\text { (mean } \pm \text { SD) }\end{array}$ & $\begin{array}{c}\text { Websites } \\
\text { of hospitals ranked } \\
\text { as } 91-100 \\
\text { in the rNCQA } \\
\text { (mean } \pm \text { SD) }\end{array}$ & $p^{*}$ \\
\hline $\begin{array}{l}\text { Access } \\
\text { to knowledge }\end{array}$ & $9.60 \pm 3.86$ & $11.20 \pm 4.54$ & 0.500 \\
$\begin{array}{l}\text { Knowledge } \\
\text { creation } \\
\text { Knowledge } \\
\text { transfer }\end{array}$ & $1.67 \pm 2.36$ & $3.67 \pm 1.89$ & 0.046 \\
$\begin{array}{l}\text { Scope } \\
\text { of information }\end{array}$ & $19.40 \pm 1.35$ & $8.33 \pm 1.76$ & 0.400 \\
$\begin{array}{l}\text { Total website } \\
\text { quality } \\
\text { score }\end{array}$ & $39.67 \pm 1.29$ & $18.20 \pm 1.14$ & 0.026 \\
\hline
\end{tabular}

* Mann-Whitney U test.

rNCQA - ranking of the best multispecialty hospitals released by the Polish National Center for Quality Assessment in Healthcare.

of the rNCQA revealed statistically significant relations in only 3 cases. A moderate statistically significant negative correlation was found between the score for knowledge creation and the result of the rNCQA in the "management" area (Spearman's rho coefficient $=-0.53$; $p<0.05)$. In turn, moderate statistically significant positive correlations were found between the score for the scope of information on the website and the result of the rNCQA in the "management" area, and between the score for the scope of information and the total rNCQA result (Spearman's rho coefficients 0.56 and 0.46 , respectively; $p<0.05$ for both) (Table 4 ).

Table 4. The analysis of the correlation between the website quality and the results of the rNCQA; Spearman's rho coefficients

Tabela 4. Analiza korelacji pomiędzy jakością strony internetowej a wynikami rCMJ; współczynnik korelacji rho Spearmana

\begin{tabular}{|l|c|c|c|c|}
\hline Website quality & $\begin{array}{c}\text { Management } \\
\text { rNCQA }\end{array}$ & $\begin{array}{c}\text { Quality } \\
\text { of care } \\
\text { rNCQA }\end{array}$ & $\begin{array}{c}\text { Medical } \\
\text { care } \\
\text { rNCQA }\end{array}$ & rNCQA \\
\hline $\begin{array}{l}\text { Access } \\
\text { to knowledge }\end{array}$ & -0.14 & -0.19 & -0.28 & -0.17 \\
$\begin{array}{l}\text { Knowledge } \\
\text { creation }\end{array}$ & $-0.53^{*}$ & -0.19 & -0.28 & -0.29 \\
$\begin{array}{l}\text { Knowledge } \\
\text { transfer }\end{array}$ & 0.11 & 0.32 & 0.25 & 0.16 \\
$\begin{array}{l}\text { Scope } \\
\text { of information }\end{array}$ & $0.56^{*}$ & 0.29 & 0.38 & $0.46^{*}$ \\
$\begin{array}{l}\text { Total website } \\
\text { quality score }\end{array}$ & -0.21 & -0.21 & -0.23 & -0.22 \\
\hline
\end{tabular}

* Statistically significant rho coefficients. 


\section{Provision of e-health services}

The comparison of the numbers of e-health services accessible through the hospital websites did not show any significant difference between the 2 groups of hospitals (mean $\pm S D 3.00 \pm 1.25$ and $2.7 \pm 0.95$, respectively; Mann-Whitney $U$ test, $Z=0.44, p=0.66)$. In general, apart from online booking, e-health services were rarely available through hospital websites. Online booking was available on $85 \%$ of the sites assessed; educational resources for patients on 60\%; access to electronic medical records for patients and programs supporting lifestyle changes were both available on $30 \%$ of the websites (Table 5).

Table 5. The availability of e-health services

Tabela 5. Dostęp do usług e-zdrowia

\begin{tabular}{|c|c|c|}
\hline \multirow[b]{2}{*}{ Type of e-health service } & \multicolumn{2}{|c|}{ Availability of e-health service } \\
\hline & $\begin{array}{c}\text { websites } \\
\text { of hospitals } \\
\text { ranked as } 1-10 \\
\text { in the rNCQA } \\
n(\%)\end{array}$ & $\begin{array}{c}\text { websites } \\
\text { of hospitals } \\
\text { ranked as } 91-100 \\
\text { in the rNCQA } \\
n(\%)\end{array}$ \\
\hline 1. Online booking & $7(70)$ & $10(100)$ \\
\hline $\begin{array}{l}\text { 2. Patient access to electronic } \\
\text { medical record }\end{array}$ & $5(50)$ & $1(10)$ \\
\hline $\begin{array}{l}\text { 3. Online consultations } \\
\text { for patients }\end{array}$ & $0(0)$ & $0(0)$ \\
\hline $\begin{array}{l}\text { 4. Telemonitoring of patients } \\
\text { with chronic conditions } \\
\text { (tele-ECG, electronic diary) }\end{array}$ & $0(0)$ & $0(0)$ \\
\hline $\begin{array}{l}\text { 5. Teleconsultation services } \\
\text { for other healthcare } \\
\text { providers }\end{array}$ & $0(0)$ & $1(10)$ \\
\hline $\begin{array}{l}\text { 6. Educational resources } \\
\text { addressed to patients }\end{array}$ & $4(40)$ & $8(80)$ \\
\hline $\begin{array}{l}\text { 7. Educational resources for } \\
\text { health professionals }\end{array}$ & $0(0)$ & $0(0)$ \\
\hline $\begin{array}{l}\text { 8. Online program } \\
\text { supporting healthy lifestyle } \\
\text { (weight loss, addictions) }\end{array}$ & $4(40)$ & $2(20)$ \\
\hline $\begin{array}{l}\text { 9. Video streaming } \\
\text { addressed to patients }\end{array}$ & $1(10)$ & $1(10)$ \\
\hline $\begin{array}{l}\text { 10. Video streaming } \\
\text { addressed to health } \\
\text { professionals }\end{array}$ & $0(0)$ & $0(0)$ \\
\hline $\begin{array}{l}\text { 11. Use of social media } \\
\text { for promotion and } \\
\text { communication with users }\end{array}$ & $0(0)$ & $0(0)$ \\
\hline
\end{tabular}

\section{Discussion}

Contrary to expectations, our study did not reveal significant differences in website quality between the hospitals from the first and the last 10 positions in the rNCQA "Golden Hundred". However, a difference was seen in the scores achieved in the category of knowl- edge creation, reflecting openness to capturing information from users. Unexpectedly, an open attitude was significantly higher among the last 10 than among the top 10 hospitals in the "Golden Hundred". In turn, the first 10 hospitals attained higher scores in the category of the scope of information. It is also worth emphasizing that the score in this category was correlated with the rNCQA total score and with the rNCQA score for "management". Interestingly, there was a significant negative correlation between results obtained in the area of "management" and the scores achieved in the category of knowledge creation in the website quality assessment.

In our study, we did not assess the availability of websites maintained by hospitals. However, earlier studies aiming at assessing the quality of websites maintained by hospitals usually provided some insight into the rates of availability of such sites. A study from 2004 indicated that $82 \%$ of the general hospitals in Norway had their own websites. ${ }^{16}$ A study carried out by Maifredi et al. in 2009 showed that in Italy, $64.3 \%$ of public hospitals (419 out of 652 ) and $56.1 \%$ of private hospitals (344 out of 613) had their own websites. ${ }^{11}$

In our study, the total scores reflecting the quality of hospital websites were about 40 points out of a maximum of 80 . In a study by Mira et al., the scores achieved by the websites assessed expressed as a percentage of maximum value ranged from $23 \%$ to $62 \%$, with an average of $43 \% .{ }^{10}$ Interestingly, the methodology for selecting the hospitals included in that analysis was similar to the method applied in our study, as it was based on the Spanish ranking "Hospitals Top 20 2003". In a later study by this team, the websites of American, British and Spanish hospitals were assessed with the same tool. The percentage scores achieved by Spanish hospitals were nearly the same as in the study from 2006: the mean score was $47 \%$ and the range was $29-68 \% .^{17}$ The mean score for the websites of American hospitals was 50\% (range: 42-61\%) and that for British hospitals it was 54\% (range: 39-70\%). Maifredi et al. carried out the assessment of the websites of Italian hospitals based on 89 individual criteria (each criterion could be assigned 1 point). The mean score achieved by public entities was 41.9; the mean score for private institutions was 30.8. ${ }^{11}$ In a study of Lee et al., the strategy of evaluation was based on similar criteria as in our study. They assessed 20 hospitals from North America and Asia, applying criteria stemming from knowledge mechanisms (access, creation and transfer). ${ }^{13}$ The main objective of the study was the elucidation of potential differences in the quality of hospital websites from the 2 continents. Therefore, mean integrated score values were not provided. Lee et al. used a weighting and scoring strategy resulting in final scores that could assume values from 0 to 5 . A comparison of sub-domain scores showed that the top 7 hospitals convincingly utilizing all 3 knowledge mechanisms were situated in North America. ${ }^{13}$ Finally, a rank- 
ing of 2407 websites of US hospitals performed by Huerta et al. demonstrated that mean scores (range: 0-10) for criteria including accessibility, content, marketing, technology, and usability were 5.08, 6.49, 5.03, 4.43, and 5.16 , respectively. ${ }^{18}$

Our study found that the availability of e-health services other than online booking of appointments was very limited. In the sample of 20 hospitals, online booking was provided by 17 hospitals. In other studies, the provision of e-health services varied considerably. A study of public hospitals in Greece by Patsioura et al. revealed that none provided online appointment scheduling or online access to medical test results. ${ }^{9}$ Maifredi et al. reported that $80 \%$ of the hospitals assessed in Italy provided users with the option of communicating online, but only $18 \%$ allowed reservations of medical services and only $1 \%(n=8)$ provided a healthcare forum. ${ }^{11}$ Mangotra and Mahajan found that $85 \%$ of selected 119 hospitals in India offered appointment scheduling by e-mail. ${ }^{19}$ Huang reported that an option for online checkin was provided by $31.1 \%$ of 2385 Chinese hospitals included in a study from $2014 .^{20}$

What may be suprising, Polish hospital did not refer to social media platforms on their websites. A study performed by Gallant et al. revealed that all 14 top-ranked US hospitals used social media (Facebook, Twitter) to provide health information to patients. A considerable number of hospitals also maintained blogs with health information addressed to patients. ${ }^{21}$ Van de Belt et al. performed an analysis of 732 Western European general hospitals and showed that the use of social media increased significantly over time, from $2 \%$ to $19.7 \%$ in the case of YouTube and from 10\% to $67 \%$ in the case of Facebook. ${ }^{22}$ Huang et al. reported that $21.8 \%$ of Chinese hospitals provided some type of information on their websites in the form of YouTube videos. ${ }^{23}$

Our study had some limitations. First of all, the sample of hospital websites was limited and may not be representative of Polish hospitals. However, the main objective of the study was to evaluate correlations between the results of the ranking of performance of a hospital and the quality of the website of the same hospital. Furthermore, the analysis involved hospitals from among the 100 best hospitals in the rNCQA To our knowledge, it is the first study reporting a comprehensive assessment of the quality of hospital websites in Poland. The results of the rNCQA for multispecialty hospitals were explored to some extent by Owczarek and Zdonek in relation to the quality of websites maintained by these hospitals. ${ }^{24}$ Interestingly, those researchers carried out their assessment of the accessibility of websites with the Utilitia validator tool ${ }^{25}$ based on the Web Content Accessibility guidelines. ${ }^{26}$ Their study revealed that only 33 websites fulfilled the criteria of accessibility and 65 were assessed as only partially accessible.

\section{Conclusions}

It seems that Internet presence is still a neglected strategy for communicating about health services provided by Polish hospitals. Even the best hospitals, according to a ranking focused on the quality of services and management, do not offer websites of high quality. Our evaluation found that the average scores for website quality were about $50 \%$ of maximum score. Furthermore, the relation between the quality of websites and the quality of hospitals in the national rankings was not straightforward. Paradoxically, the knowledge creation category was better addressed by websites of hospitals that scored lower in the ranking developed by the NCQA. However, the scope of information provided on websites was related to both the total rNCQA score and rNCQA score for "management". It seems that an initiative promoting the quality of websites maintained by healthcare providers could improve the current situation. A ranking of best practices in the area of Internet presence would be another option to address this shortcoming. The expenditures required for developing and maintaining attractive websites enabling communication with patients and their families is relatively insignificant in comparison to the overall budget of modern medical institution.

\section{References}

1. Risk A, Dzenowagis J. Review of Internet health quality initiatives. $J$ Med Internet Res. 2001;3(4):e28. doi:10.2196/jmir.3.4.e28

2. Gagliardi A, Jadad AR. Examination of instruments used to rate quality of health information on the internet: Chronicle of a voyage with an unclear destination. BMJ. 2002;324(7337):569-573. doi: 10.1136/bmj.324.7337.569

3. Boyer C. The Internet and health: International approaches to evaluating the quality of web-based health information. In: George C, Whitehouse D, Duquenoy P, eds. eHealth: Legal, Ethical and Governance Challenge. Berlin-Heidelberg, Germany: Springer-Verlag; 2013:245-274.

4. Health on the Net Foundation Website (HON). The HONcode: Principles. https://www.hon.ch/HONcode/Pro/Visitor/visitor.html. Accessed August 21, 2017.

5. Rocha Á, Victor A, Brandão PL. Quality of health web sites: Dimensions for a wide evaluation. In: Grabis J, Kirikova M, eds. BIR 2011: Perspectives in Business Informatics Research. Berlin-Heidelberg, Germany: Springer-Verlag; 2011:254-266.

6. Act on healthcare services from April 15, 2011. Ustawa z dnia 15 kwietnia 2011 r. o działalności leczniczej. DzU z 2011 r. $\mathrm{Nr}$ 112, poz 654. http://prawo.sejm.gov.pl/isap.nsf/download.xsp /WDU20111120654/T/D20110654L.pdf. Accessed August 21, 2017.

7. Fulda PO, Kwasik A. Consumer health information provided by library and hospital websites in the South Central Region. J Med Libr Assoc. 2004;92(3):373-375. https://www.ncbi.nlm.nih .gov/pmc/articles/PMC442181/. Accessed August 21, 2017.

8. Randeree E, Rao HR. E-health and assurance: Curing hospital websites. Int J Electron Healthc. 2004;1(1):33-46. doi:10.1504 /IJEH.2004.004653

9. Patsioura F, Kitsiou S, Markos A. Evaluation of Greek public hospital websites. Proceedings of International Conference on E-business (ICE-B). 2009:223-229.

10. Mira JJ, Llinás G, Tomás O, Pérez-Jover V. Quality of websites in Spanish public hospitals. Med Inform Internet Med. 2006;31(1):23-44. doi:10.1080/14639230500519940

11. Maifredi G, Orizio G, Bressanelli M, et al. Italian hospitals on the web: A cross-sectional analysis of official websites. BMCMed Inform Decis Mak. 2010;10:17. doi:10.1186/1472-6947-10-17 
12. Nah FF, Siau $K$, Tian $Y$, Ling M. Knowledge management mechanisms in e-commerce: A study of online retailing and action sites. J Comput Inf Syst. 2002;42:119-128. doi:10.1080/08874417.2002 .11647616

13. Lee CS, Goh DH, Chua A. An analysis of knowledge management mechanisms in healthcare portals. J Libr Inf Sci. 2010;42(1):20-44. doi:10.1177/0961000609351371

14. Minifie JR, Dietert J, Middlebrook B. E-international hospital websites strategy comparisons. Mountain Plains Journal of Business and Economics. 2005;6:62-72.

15. Centrum Monitorowania Jakości (CMJ). Ranking Bezpieczny Szpital 2016. http://www.cmj.org.pl/ranking/wyniki_2016/. Accessed May 10, 2017.

16. Norum J, Moen MA. The websites of Norwegian hospitals: Do they meet national guidelines and patients' expectations? J Telemed Telecare. 2004;10(5):272-276. doi:10.1258/135763304202 6260

17. Llinás G, Rodríguez-Iñesta D, Mira JJ, Lorenzo S, Aibar C. A comparison of websites from Spanish, American and British hospitals. Methods Inf Med. 2008;47:124-130.

18. Huerta TR, Hefner JL, Ford EW, McAlearney AS, Menachemi N. Hospital website rankings in the United States: Expanding benchmarks and standards for effective consumer engagement. J Med Internet Res. 2014;16(2):e64. doi:10.2196/jmir.3054

19. Mangotra M, Mahajan R. Assessment of hospital websites as potential KM tools: A study of Indian hospitals. The IUP Journal of Knowledge Management. 2012;10(4):14-25.

20. Huang E, Wang J, Liu T. Interactive e-health tools for patients on Chinese hospitals' websites. Int J Healthc Manag. 2014;7(2):75-83. doi: 10.1179/2047971914Y.0000000069

21. Gallant LM, Irizarry C, Boone G, Kreps G. Promoting participatory medicine with social media: New media applications on hospital websites that enhance health education and epatients' voice. J Particip Med. 2011;3:e49. https://participatorymedicine.org/journal /evidence/research/2011/10/31/promoting-participatory-medicine-with-social-media-new-media-applications-on-hospitalwebsites-that-enhance-health-education-and-e-patients-voices/. Accessed August 21, 2017.

22. Van de Belt TH, Berben SA, Samsom M, Engelen LJ, Schoonhoven L. Use of social media by Western European hospitals: Longitudinal study. J Med Internet Res. 2012;14(3):e61. doi:10.2196/jmir.1992

23. Huang E, Liu T, Wang J. E-health videos on Chinese hospitals' websites. Int J Healthc Manag. 2014;7(4):273-280.

24. Owczarek T, Zdonek D. Kryteria oceny strony internetowej szpitali w kontekście innowacyjnych strategii w sektorze usług zdrowotnych. Zeszyty Naukowe Politechniki Ślaskiej, Seria: Organizacja i Zarzq̨dzanie. 2014;74:581-591. http://yadda.icm.edu.pl/yadda /element/bwmeta1.element.baztech-386ed156-e227-4fca-8224 -4b840d1fb9fb/c/owczarek_ZNPSLOZ_74_2014.pdf. Accessed August 21, 2017.

25. Utilitia website validator (Utilitia). https://www.validator.utilitia.pl/. Accessed August 21, 2017.

26. Web Accessibility Initiative. Web Content Accessibility Guidelines (WCAG) Overview. https://www.w3.org/WAl/intro/wcag. Accessed August 21, 2017. 